Prepared in cooperation with Texas Parks and Wildlife Department

\title{
Winter Ecology and Habitat Use of Lesser Prairie-Chickens in West Texas, 2008-11
}

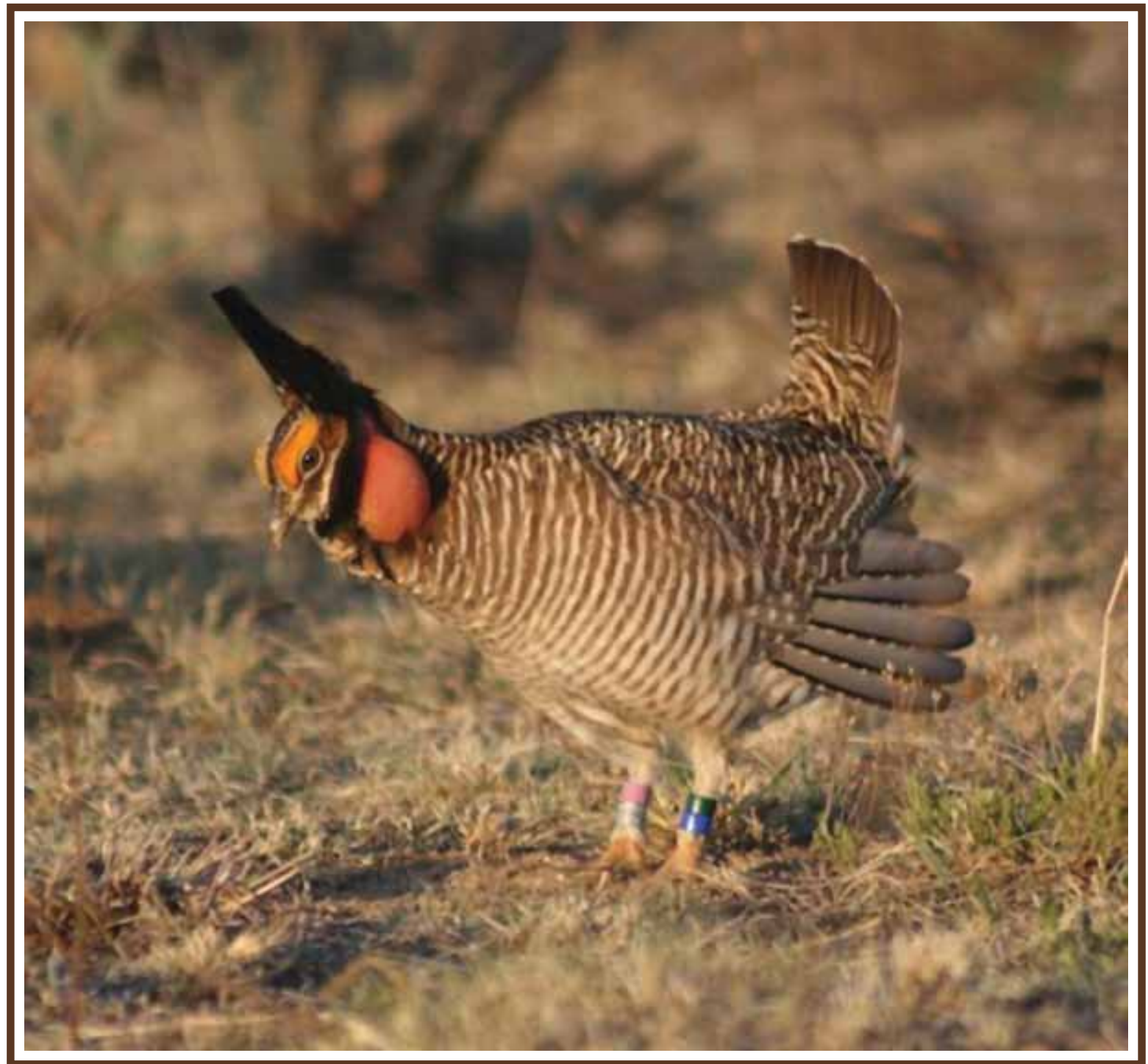

Open-File Report 2012-1073 



\section{Winter Ecology and Habitat Use of Lesser Prairie-Chickens in West Texas, 2008-11}

By Clint W. Boal and Nicholas E. Pirius

Prepared in cooperation with Texas Parks and Wildlife Department

Open-File Report 2012-1073 


\title{
U.S. Department of the Interior \\ KEN SALAZAR, Secretary \\ U.S. Geological Survey \\ Marcia K. McNutt, Director
}

\section{U.S. Geological Survey, Reston, Virginia: 2012}

\author{
This and other USGS information products are available at http://store.usgs.gov/ \\ U.S. Geological Survey \\ Box 25286, Denver Federal Center \\ Denver, CO 80225 \\ To learn about the USGS and its information products visit http://www.usgs.gov/ \\ 1-888-ASK-USGS
}

\begin{abstract}
Any use of trade, product, or firm names is for descriptive purposes only and does not imply endorsement by the U.S. Government.

Although this report is in the public domain, permission must be secured from the individual copyright owners to reproduce any copyrighted materials contained within this report.
\end{abstract}

Suggested citation:

Boal, C.W., and Pirius, N.E., 2012, Winter ecology and habitat use of lesser prairie-chickens in west Texas, 2008-11: U.S. Geological Survey Open-File Report 2012-1073, 9 p. 


\section{Acknowledgments}

Access to private property was provided by various landowners. We thank A.E Escobar, C.G. Frey, C. Kveton, L. Rindlisbacher, and A. Teague helped with fieldwork and B. Grisham, D. Holt, D. Lucia, B. Skipper and M. Vanlandeghem for their support both in the lab and in the field. We thank D. Haukos and H. Whitlaw for service on the graduate student committee, and substantive review comments on the graduate thesis stemming from this research. We thank J. Baccus and D. Lucia for providing helpful reviews of the report. Financial and logistical support for this project was provided by Texas Parks and Wildlife Department, USGS Texas Cooperative Fish and Wildlife Research Unit, and Texas Tech Department of Natural Resources Management. 



\section{Contents}

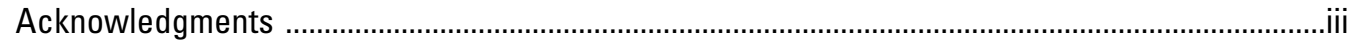

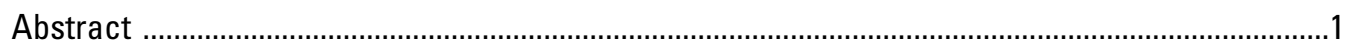

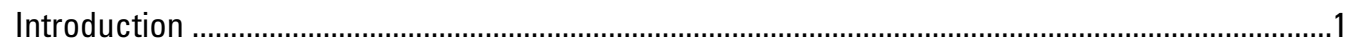

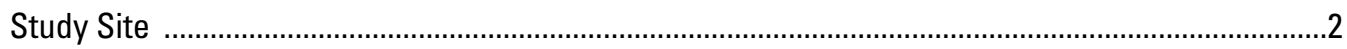

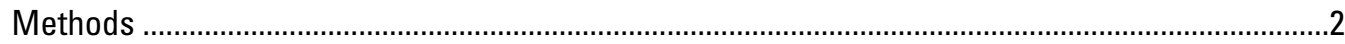

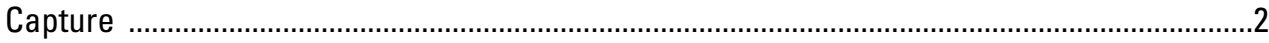

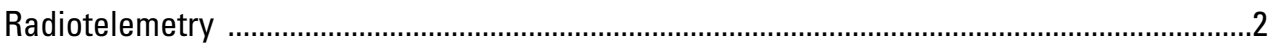

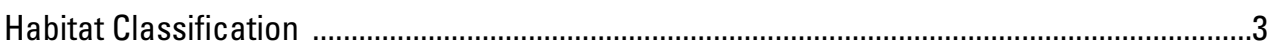

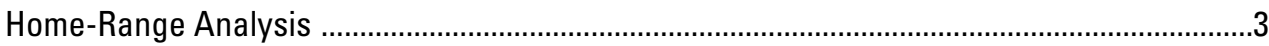

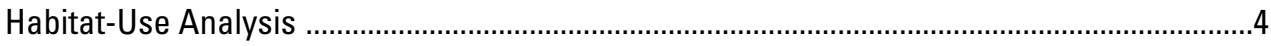

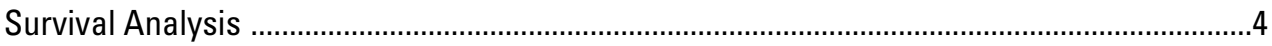

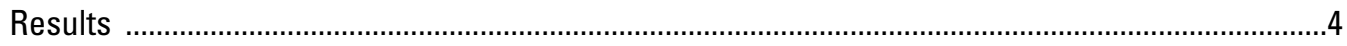

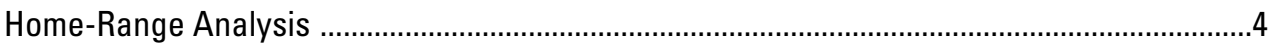

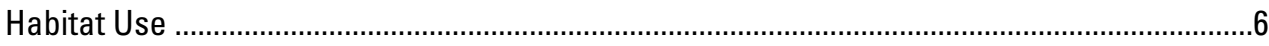

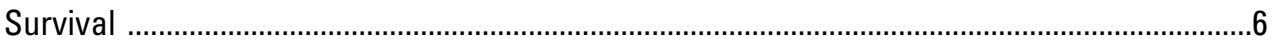

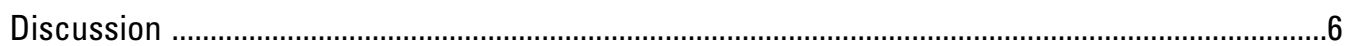

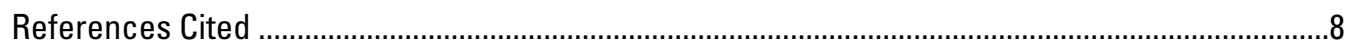

\section{Figure}

1. Graphs showing percentage of lesser prairie-chicken (Tympanuchus pallidicinctus) locations at distance intervals from $A$, lek of capture, $B$, nearest known lek, and $C$, nearest water source in the Southern High Plains of Texas from September 1 through February 28, 2008-9, 2009-10, and 2010-11

\section{Tables}

1. Land cover types used for determining habitat types for lesser prairie-chickens (Tympanuchus pallidicinctus) in the Southern High Plains of Texas during the nonbreeding seasons of 2008-10

2. Estimated home ranges (hectares) based on 95 percent fixed kernel estimator (HR), minimum weekly movements (MWM), minimum distance to lek of capture (DLC) for male and female lesser prairie-chickens (Tympanuchus pallidicinctus) in the Southern High Plains of Texas in the 2008-9, 2009-10, and 2010-11 nonbreeding seasons

3. Estimated minimum distance to nearest known leks (DNL) and minimum distance to nearest available water source $\left(\mathrm{DH}_{2} \mathrm{O}\right)$ for male and female lesser prairiechickens (Tympanuchus pallidicinctus) in the Southern High Plains of Texas in the 2008-9, 2009-10, and 2010-11 nonbreeding seasons

4. Nonbreeding-season habitat use relative to availability of lesser prairie-chickens (Tympanuchus pallidicinctus) in the Southern High Plains of Texas from September 1 through February 28 for 2008-9, 2009-10, and 2010-11

5. Ranking of a priori candidate models predicting survival for lesser-prairie chickens (Tympanuchus pallidicinctus) in the Southern High Plains of Texas from September 1 through February 28 for 2008-9, 2009-10, and 2010-11 


\section{Conversion Factors}

\section{SI to Inch/Pound}

\begin{tabular}{lll}
\hline \multicolumn{1}{c}{ Multiply } & By & \multicolumn{1}{c}{ To obtain } \\
\hline centimeter $(\mathrm{cm})$ & Length & inch (in.) \\
millimeter $(\mathrm{mm})$ & 0.3937 & inch (in.) \\
meter $(\mathrm{m})$ & 0.03937 & foot (ft) \\
kilometer $(\mathrm{km})$ & 3.281 & mile (mi) \\
kilometer $(\mathrm{km})$ & 0.6214 & mile, nautical (nmi) \\
meter $(\mathrm{m})$ & 0.5400 & yard (yd) \\
\hline & 1.094 & \\
\hline square meter $\left(\mathrm{m}^{2}\right)$ & Area & acre \\
hectare $(\mathrm{ha})$ & 0.0002471 & acre \\
square meter $\left(\mathrm{m}^{2}\right)$ & 2.471 & square foot (ft $\left.{ }^{2}\right)$ \\
hectare $(\mathrm{ha})$ & 10.76 & square mile (mi $\left.{ }^{2}\right)$ \\
\hline & 0.003861 & \\
\hline microliter (uL) & Volume & Liter (L) \\
liter (L) & 106 & ounce, fluid (fl. oz) \\
liter (L) & 33.82 & pint (pt) \\
liter (L) & 2.113 & quart (qt) \\
liter (L) & 1.057 & gallon (gal) \\
\hline gram (g) & 0.2642 & \\
\hline
\end{tabular}

Temperature in degrees Celsius $\left({ }^{\circ} \mathrm{C}\right)$ may be converted to degrees Fahrenheit $\left({ }^{\circ} \mathrm{F}\right)$ as follows:

${ }^{\circ} \mathrm{F}=\left(1.8 x^{\circ} \mathrm{C}\right)+32$ 


\title{
Winter Ecology and Habitat Use of Lesser Prairie- Chickens in West Texas, 2008-11
}

\author{
By Clint W. Boal' and Nicholas E. Pirius ${ }^{2}$
}

\section{Abstract}

The lesser prairie-chicken (Tympanuchus pallidicinctus) has experienced declines in population and occupied range by more than 90 percent since the late 1800s. The lesser prairiechicken has been listed as a candidate species for protection under the Endangered Species Act and is undergoing review for actual listing. Populations and distribution of lesser prairiechickens in Texas are thought to be at or near all time lows. These factors have led to substantially increased concern for conservation of the species. It is apparent that sound management and conservation strategies for lesser prairiechickens are necessary to ensure the long-term persistence of the species. To develop those strategies, basic ecological information is required. Currently, there is a paucity of data on the wintering ecology of the species. We examined home range, habitat use, and survival of lesser prairie-chickens during the winters of 2008-9, 2009-10, and 2010-11 in sand shinnery oak (Quercus havardii) landscapes in west Texas. We captured and radio-tagged 53 adult lesser prairie-chickens. We obtained sufficient locations to estimate winter homerange size for 23 individuals. Home-range size did not differ between years or by sex. Although female prairie-chickens had slightly larger home ranges $(503.5 \pm 34.9$ ha) compared to males $(489.1 \pm 34.9 \mathrm{ha})$, the differences were not significant $\left(t_{2}=0.05, P=0.96\right)$. During the nonbreeding season, we found that 97.2 percent of locations of male and female prairie-chickens alike were within 3.2 kilometers $(\mathrm{km})$ of the lek of capture. Most locations (96.8\%) were within $1.7 \mathrm{~km}$ of a known lek and almost all locations (99.9\%) were within $3.2 \mathrm{~km}$ of an available water source. Habitat cover types were not used proportional to occurrence within the home ranges, grassland dominated areas with sand shinnery oak were used more than available, and sand sagebrush (Artemisia filifolia) areas dominated with grassland as well as sand sagebrush areas dominated with bare ground were both used less than available. Survival rates during the first 2 years (year 1:

${ }^{1}$ U.S. Geological Survey Cooperative Fish and Wildlife Research Unit, Department of Range, Wildlife, and Fisheries Management, Texas Tech University, Lubbock, TX 79409-2120.

${ }^{2}$ Texas Cooperative Fish and Wildlife Research Unit, Department of Natural Resources Management, Texas Tech University, Lubbock, TX 79409.
$0.846 \pm 0.141$; year $2: 0.827 \pm 0.092$ ) were among the highest ever reported for the species during the nonbreeding season. Survival was markedly decreased in year $3(0.572 \pm 0.136)$ and resulted in an overall nonbreeding season average of 0.721 $( \pm 0.0763)$. These are still among the highest survival rates reported for the species; it does not appear that winter season mortality is a strong limiting factor in lesser prairie-chicken persistence in the study area.

\section{Introduction}

The lesser prairie-chicken (Tympanuchus pallidicinctus) has experienced severe declines in both population and range since the 1800s (Taylor and Guthery 1980a; Hagen and others, 2004). Davis and others (unpub. data, 2008) suggested that 90 percent of the original range of lesser prairie-chickens is no longer suitable for occupancy. With the evidence of long term declines in population and historic range, the lesser prairiechicken is currently listed as "warranted but precluded" under the Endangered Species Act (U.S. Fish and Wildlife Service, 2008). The status "warranted but precluded" illustrates that sufficient evidence and probable cause for listing for Federal protection are present; however, at the current time there are other species with a more critical need for listing. The current distribution of lesser prairie-chickens is limited to areas of Colorado, Kansas, New Mexico, Oklahoma, and Texas (Davis and others, unpub. data, 2008). As of 2008, biologists agreed that overall population estimates range from 30,000 to 50,000 breeding birds (Davis and others, unpub. data, 2008). Davis and others (unpub. data, 2008) also suggested that the lesser prairie-chicken benefited from small amounts of conversion of native rangeland to cropland; however, extension of this practice was proved to be detrimental.

The reproductive ecology and brood-rearing period for the lesser prairie-chicken has been the main focus of previous studies. Comparatively little research effort has addressed the nonbreeding ecology of the species in terms of movements (Taylor and Guthery, 1980b), habitat use (Donaldson, 1969; Olawsky and Smith, 1991; Davis and others, unpub. data, 2008), home range (Taylor and Guthery 1980b; Jamison, 2000; Toole, 2005; Kukal, 2010), or survival (Hagen and others, 2005; Pitman and others, 2006a; Hagen and others, 
2007). Information on the nonbreeding season ecology of the lesser prairie-chicken is limited in Texas as well as other areas across its range. Information suggests that movements by lesser prairie-chickens increase from October to November but decrease from January to February (Taylor and Guthery, 1980b). Over the winter, lesser prairie-chickens are also known to form flocks; Taylor and Guthery (1980b) found flocks with up to 100 lesser prairie-chickens feeding in a grain field. Few studies have examined the over-winter ecology of lesser prairie-chickens. The primary objectives of this study were to assess sex-specific home-range size, habitat use, and survival of lesser prairie-chickens during the fall and winter on the Southern High Plains of Texas. This study will provide baseline information on winter ecology and survival of lesser prairie-chickens in west Texas and facilitate information-based management decisions for the study area.

\section{Study Site}

The study site was located on private lands in Cochran, Hockley, Terry, and Yoakum Counties of the Southern High Plains of Texas. The study site consisted of primarily flat terrain with intermixed sand dunes. The site was dominated by sand shinnery oak (Quercus havardii) and sand sagebrush (Artemisia filifolia) with grasses such as sand bluestem (Andropogon gerardii spp. hallii), little bluestem (Schizachyrium scoparium), sand dropseed (Sporobolus cryptandrus), purple three-awn (Aristida purpurea), blue grama (Bouteloua gracilis), buffalograss (Buchloe dactyloides), and various forbs (Crawford and Bolen, 1976). The area surrounding the study site was dominated by honey mesquite (Prosopis glandulosa), grassland pastures, and agricultural fields of cotton (Gossypium spp.), grain sorghum (Sorghum spp.), sunflower (Helianthus spp.), and peanuts (Arachis spp.). The dominant soil type was a Brownfield fine sand, which is defined by more than or equal to 50 centimeters $(\mathrm{cm})$ of fine sand on top of a sandy loam that exhibits a water infiltration rate at approximately $70 \mathrm{~cm} /$ hour (h) (Pettit, 1979). Cattle grazing and crop production were the primary uses of the study area as well as substantial amounts of oil production. As of 2006, Yoakum County had about 6,500 oil wells (Railroad Commission of Texas, 2006). There were few active oil wells located on the study site; however, abandoned oil pads were still present and, occasionally, used as leks.

We compiled weather data from the Mesonet weather recording station in Sundown, Tex., (Texas Tech University, 2011). Average annual precipitation for 2002 through 2010 was $45.3 \mathrm{~cm}$. Annual precipitation for 2008 through 2010 was $38.8 \mathrm{~cm}, 34.4 \mathrm{~cm}$, and $58.2 \mathrm{~cm}$, respectively. Average nonbreeding season precipitation for 2002 through 2010 was $16.7 \mathrm{~cm}$. The nonbreeding period (September through February) average rainfall for the 2008-9, 2009-10, and 2010-11 seasons was $19.6 \mathrm{~cm}, 18.5 \mathrm{~cm}$, and $12.2 \mathrm{~cm}$.

\section{Methods}

\section{Capture}

We captured lesser prairie-chickens in the spring (early March to Late April) and fall (early September to midOctober) with walk-in funnel traps (Haukos and others, 1989). We determined sex of captured birds on the basis of tail pattern, pinnae length and presence of an eye comb (Copelin, 1963). White spotting within $2.5 \mathrm{~cm}$ of the feather tip of the ninth and tenth primary flight feathers indicated a juvenile, whereas the absence of white spotting within $2.5 \mathrm{~cm}$ indicated an adult (Copelin, 1963). We also measured body mass, tarsus length, and an unflattened wing cord. We collected six to eight breast feathers and a blood sample from each bird for contribution to a separate study examining the genetic diversity of lesser prairie-chickens in Texas; we drew blood (a 2-3 uL tube, and two 1-uL tubes) from the brachial vein by using a 20 -gage needle. We equipped each bird with an aluminum Texas Parks and Wildlife Department blunt-end leg band and three separate color bands, which corresponded to the lek of capture and allowed visual identification of individual birds. Following guidelines by Warner and Etter (1983), radio transmitter weights should fall below 2.3 percent of total body mass so as to not decrease survival. On our study site, lesser prairie-chickens weighed about 600-800 grams (g), for which transmitter weights should range from $13.8 \mathrm{~g}$ to $18.4 \mathrm{~g}$. Conservatively, we equipped each captured lesser prairie-chicken with a $9 \mathrm{~g}$ American Wildlife Enterprise "necklace" style VHF radio transmitter (American Wildlife Enterprises, Monticello, Florida, USA), which was set with an 8-h mortality sensor.

\section{Radiotelemetry}

We obtained nonbreeding season relocations of lesser prairie-chickens from September 1 through February 28 of 2008-9, 2009-10, and 2010-11. We used an Advanced Telemetry System R-2000 Receiver (Advanced Telemetry Systems, Isanti, Minnesota, USA) and a hand-held 3-element Yagi antenna to triangulate prairie-chicken position. We obtained three to four bearings (Cochran and Lord, 1963) from different locations all within 15-minute (min) intervals to limit error based on movements. We attempted to obtain two to three locations or more for each radio-tagged bird per week and rotated relocation events among three diurnal periods of $0600-1000 \mathrm{~h}, 1001-1400 \mathrm{~h}$, and $1401-1900 \mathrm{~h}$ to obtain even amounts of locations per period per individual across the nonbreeding period. We used program LOAS 4.0 (location of a signal) (Ecological Software Solutions) to obtain the Universal Transverse Mercator (UTM) coordinates derived from triangulated bearings for each location. We discarded locations from analysis if error polygons were greater than 
about a 122 meter $(\mathrm{m})$ by $122 \mathrm{~m}$ area because of the high error associated with the locations. UTM coordinates were then transferred into ArcMap 10 (ArcInfo, Environmental Systems Research Institute, Redlands, California) and plotted as a point layer over the map of the study site.

When a mortality signal occurred, we located the transmitter via homing (Mech, 1983). Upon finding a transmitter with a mortality signal, we collected all available data to determine if a mortality had occurred or if a transmitter had come unattached from a lesser prairie-chicken. When we confirmed mortality, we took photographs of the mortality location and then collected information such as condition of the transmitter, all available tracks and scat, and all feathers to facilitate the identification for cause of mortality.

\section{Habitat Classification}

We imported National Aerial Imagery Program (NAIP) aerial imagery at 1-m resolution (2008 imagery) into ArcMap 10. We described 10 different vegetation cover types based on visual interpretation of the aerial imagery (table 1). We predetermined cover types on the basis of past and current habitat management practices for our results to be comparable to previous studies (Fuhlendorf and others, 2002; Kukal, 2010) and to accurately describe the diversity of vegetation cover types on the study site. We used ArcGIS to digitize boundaries of each cover type to create a layer of vegetation cover type patches.
To confirm the delineations from aerial imagery, we ground-truthed 259 points which were located by using a hand held Global Positioning System (GPS) unit (CS60x, Garmin International Inc., Olathe, Kansas). The points were systematically placed at 400-m intervals along roads and all terrain vehicle trails across the study area. We limited data collection to a single observer to avoid observer bias. At each point we made ocular estimates at 5 percent increments of percentage of shrub (typically sand sagebrush), sand shinnery oak, grass, and bare ground out to $100 \mathrm{~m}$ in each of the four intercardinal directions (northwest, northeast, southwest, and southeast). All pastures within the study site were represented with seven to eight points to ensure accuracy of the cover type classification and delineation. We conducted ground-truthing in early spring (March and April), when the sand shinnery oak and sand sagebrush were beginning to bud (Vermeire and Wester, 2001).

\section{Home-Range Analysis}

We estimated home-range size using 95 percent fixedkernel estimates with the adehabitat package (Calenge, 2006) in Program R. We constrained our analysis of home-range size to only those birds for which we had a minimum of 25 relocations. We used a $t$-test to determine if gender-specific differences in home-range size occurred. We plotted locations and computed home ranges as layers in ArcMap 10 for use in habitat analyses described below.

Table 1. Land cover types used for determining habitat types for lesser prairie-chickens (Tympanuchus pallidicinctus) in the Southern High Plains of Texas during the nonbreeding seasons of 2008-10.

\begin{tabular}{|c|c|c|}
\hline $\begin{array}{l}\text { Cover } \\
\text { type }\end{array}$ & Classification & Description \\
\hline 1 & Agriculture (AGRI) & $\begin{array}{l}\text { Cultivated field. Typically common wheat (Triticum aestivum) or common } \\
\text { sunflower (Helianthus annuus). }\end{array}$ \\
\hline 2 & CRP grasslands (CRPG) & Monoculture of weeping lovegrass (Eragrostis curvula). \\
\hline 3 & Grassland dominated, with mesquite (GRDM) & $\begin{array}{l}\geq 70 \% \text { native grasslands (for example, Andropogon gerardii spp. hallii, } \\
\text { Schizachyrium scoparium, Sporobolus cryptandrus) with } \leq 30 \% \text { honey } \\
\text { mesquite (Prosopis glandulosa) intermixed within. }\end{array}$ \\
\hline 4 & $\begin{array}{l}\text { Grassland dominated, with sand shinnery oak } \\
\text { (GRDS) }\end{array}$ & $\begin{array}{l}\geq 70 \% \text { native grasslands with } \leq 30 \% \text { sand shinnery oak (Quercus havardii) } \\
\text { intermixed within. }\end{array}$ \\
\hline 5 & Mesquite savannah (MESA) & $\begin{array}{l}\geq 70 \% \text { honey mesquite and } \leq 30 \% \text { native grasslands and or shrubs [for example, } \\
\text { sand shinnery oak, sand sagebrush (Artemisia filifolia)] in understory. }\end{array}$ \\
\hline 6 & Reverted agriculture (REAG) & $\begin{array}{l}\text { Formerly plowed or tilled landscape that has returned to shrub land ( } \geq 50 \text { sand } \\
\text { shinnery oak, } 20-30 \% \text { native grassland, and } 20-30 \% \text { sand sagebrush). }\end{array}$ \\
\hline 9 & $\begin{array}{l}\text { Sand sagebrush dominated, with bare ground } \\
\text { (SHRDB) }\end{array}$ & $\geq 70 \%$ sand sagebrush with $\leq 30 \%$ bare ground. \\
\hline 10 & $\begin{array}{l}\text { Sand sagebrush dominated, with grassland } \\
\text { (SHRDG) }\end{array}$ & $\begin{array}{l}\geq 70 \% \text { sand sagebrush with } \leq 30 \% \text { native grassland and sand shinnery oak } \\
\text { intermixed within. }\end{array}$ \\
\hline
\end{tabular}


We calculated minimum weekly distances between locations on a 7-day time frame to assess movement patterns across the nonbreeding season. We averaged minimum across all birds for each year. We only had sufficient data to plot the average weekly movements for the 2009-10 and 2010-11 seasons. To assess areas of use, we partitioned distances into five buffer sets: $\leq 0.8,0.8-1.7,1.7-3.2,3.2-4.8$, and $\geq 4.8 \mathrm{~km}$ (Taylor and Guthery 1980b). Within these buffers, we evaluated proportions of locations to three features we believe are important to lesser prairie-chickens: lek of capture, nearest known lek, and nearest known usable water source. We defined usable water as surface water in a human-made stock tank that was constantly available throughout the year. The tank must have water at a distance of less than or equal to $10 \mathrm{~cm}$ from the top of the rim or an on-ground runoff area.

\section{Habitat-Use Analysis}

We used a Baileys Confidence interval (Bailey, 1980) method to assess use versus availability of vegetation cover types (Neu and others, 1974; Cherry, 1996). For habitat analysis, we reduced the number of locations to only those with error polygons less than $10000 \mathrm{~m}^{2}$ (about $113 \mathrm{~m} \times 113$ $\mathrm{m})$ to reduce the possibility of falsely identifying habitat types as occurring within a given home range. We used the calculated 95 percent Fixed Kernel estimated home ranges as our measure of "available" habitat for each individual. We classified "use" by taking the locations of an individual within its home range and assessing cover types to each particular point. For this analysis, we removed three cover types (agriculture, Conservation Reserve Program grasslands, and grassland-dominated areas with mesquite) that were not detected within any lesser prairie-chicken calculated home range or buffer points. To avoid any overlapping habitat types, areas that had been previously treated with the herbicide tebuthiuron for control of sand shinnery oak were placed into the cover type with which they best correspond. We used the chi-square "goodness-of-fit" technique to assess the hypothesis that lesser prairie-chickens use habitat types in proportion to what is available across the study area (Neu and others, 1974).

\section{Survival Analysis}

We conducted the survival analysis with the PROC PHREG in Statistical Analysis Software (SAS; v. 9.2, SAS Institute, Cary, North Carolina). Individuals were censored on the basis of three events: emigration off the study site, mortality, or survival beyond the end of the nonbreeding season (February 28 each year). We constructed three a priori models with the categorical variables of gender, season (2008-9, 2009-10, and 2010-11), and overall survival rate (pooled across gender and season). We calculated model weights $\left(\omega_{\mathrm{i}}\right)$ based on Akaike's Information Criteria (AIC) which were corrected for low sample size (AICc). We attempted to identify the cause of mortality based on the criteria described in Warner and Etter (1983), and examined cause specific morality pooled across season and gender.

\section{Results}

\section{Home-Range Analysis}

We obtained a total of 1,219 relocations for 53 adult lesser prairie-chickens ( 29 male and 24 female) through the 2008-9, 2009-10, and 2010-11 nonbreeding seasons; however, we obtained a sufficient number of relocations to calculate reliable home-range estimates for only 23 individuals (17 male and 6 female) and were able to compare home-range patterns between the 2009-10 and 2010-11 nonbreeding seasons only. Home-range size did not differ for male $\left(t_{1}=0.08, P=0.95\right)$ or female $\left(t_{1}=0.02, P=0.86\right)$ lesser prairie-chickens; therefore, we pooled estimates of home range for each gender across years for further analysis (table 2). Pooled home-range size averaged 503.5 ha $( \pm 34.9$ ha) for adult females $(n=6)$ and a slightly smaller 489.1 ha $( \pm 34.9$ ha) for adult males $(n=17)$. Overall homerange sizes for males and females did not differ $\left(t_{1}=0.05, P=\right.$ $0.96)$.

Table 2. Estimated home ranges (hectares) based on 95 percent fixed kernel estimator (HR), minimum weekly movements (MWM), minimum distance to lek of capture (DLC) for male and female lesser prairie-chickens (Tympanuchus pallidicinctus) in the Southern High Plains of Texas in the 2008-9, 2009-10, and 2010-11 nonbreeding seasons.

[Home ranges are reported in square meters and all distances are reported in meters]

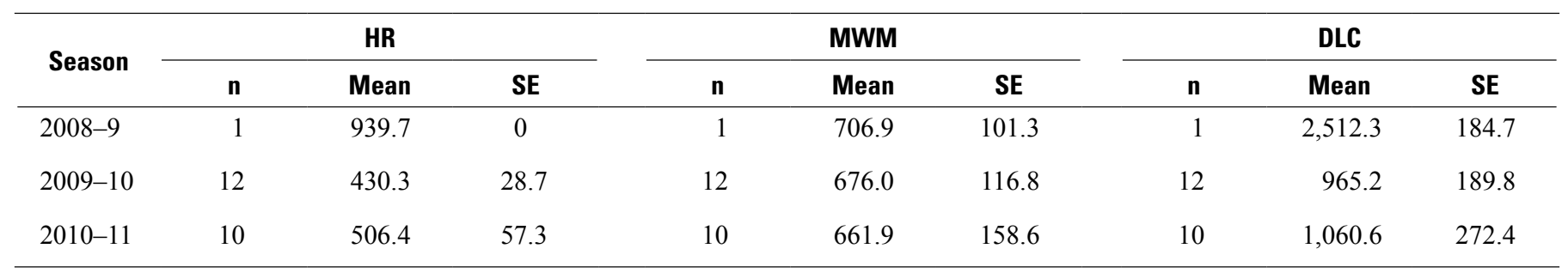



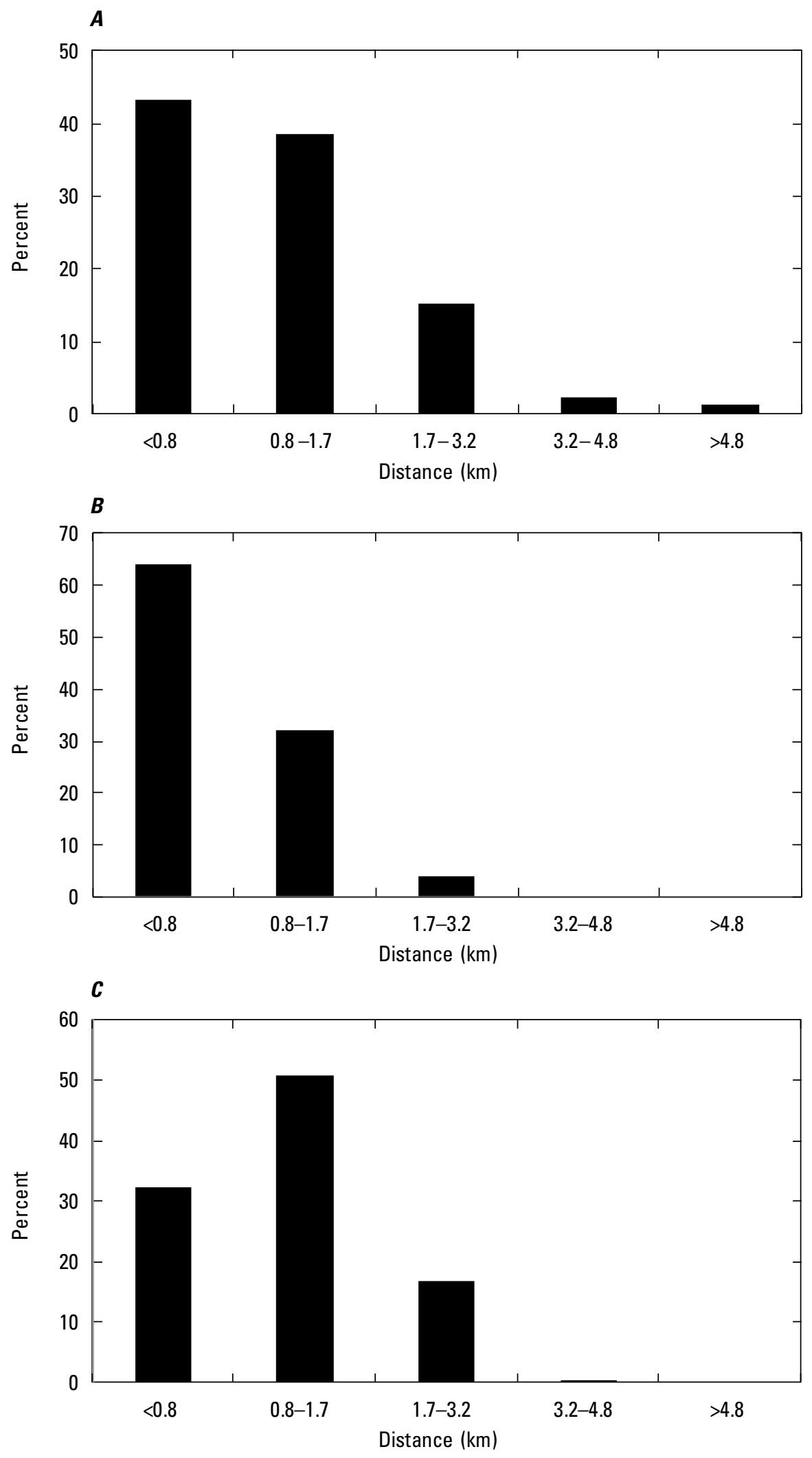

Figure 1. Percentage of lesser prairie-chicken (Tympanuchus pallidicinctus) locations at distance intervals from $A$, lek of capture, $B$, nearest known lek, and $C$, nearest water source in the Southern High Plains of Texas from September 1 through February 28, 2008-9, 2009-10, and 2010-11. 


\section{Habitat Use}

Across three nonbreeding seasons, we found that 97.2 percent of locations of both male and female prairiechickens were within $3.2 \mathrm{~km}$ of the lek of capture, whereas very few locations ( $<5.0$ percent) were recorded between 3.2 and $4.8 \mathrm{~km}$ of lek of capture (fig. 1a). Only 2.8 percent of locations were beyond the $3.2-4.8 \mathrm{~km}$ buffer; all of these locations were attributed to movements of one adult female in September of 2008. We found 96.8 percent of all locations (table 3) to be within $3.2 \mathrm{~km}$ of a known lek (fig. 1b), and 99.9 percent of all locations were within $3.2 \mathrm{~km}$ of an available water source (fig. 1c). Minimum weekly movements did not differ between seasons for male $\left(t_{25}=0.66, P=0.52\right)$ and female $\left(t_{25}=0.39, P=0.70\right)$ lesser prairie-chickens. Similarly, when genders were pooled there was no detectable difference in minimum weekly movements between the 2009-10 and 2010-11 seasons $\left(t_{25}=0.41, P=0.69\right.$; table 2$)$.

Three (agriculture, Conservation Reserve Program grassland, and grassland-dominated areas with mesquite) of the 10 classified vegetation cover types (table 1 ) were excluded from analysis because of lack of occurrence in any of the estimated home ranges. Cover types were not used proportional to occurrence within the home ranges $\left(\chi^{2}\right.$ $=1868.7, \boldsymbol{\alpha}=0.05$ ). One cover type (grassland-dominated areas with sand shinnery oak) was used more than was proportionally available (table 4). Sand sagebrush dominated with grassland and sand sagebrush dominated with bare ground were both used less than available (table 4). There was no difference between use and availability of the four remaining habitat types (mesquite savannah, reverted agriculture, sand shinnery oak, and sand shinnery dominated oak with grassland) (table 4).

\section{Survival}

The estimated survival rate for 12 individuals ( 1 male and 11 female) during the 2008-9 nonbreeding season ( $0.846 \pm$ 0.141 ) and for 21 individuals (13 male and 8 female) during

Table 3. Estimated minimum distance to nearest known leks (DNL) and minimum distance to nearest available water source $\left(\mathrm{DH}_{2} \mathrm{O}\right)$ for male and female lesser prairie-chickens (Tympanuchus pallidicinctus) in the Southern High Plains of Texas in the 2008-9, 2009-10, and 2010-11 nonbreeding seasons.

[All distances are reported in meters]

\begin{tabular}{lrrrrrrrr}
\hline \multirow{2}{*}{ Season } & \multicolumn{3}{c}{ DNL } & & \multicolumn{3}{c}{ DH $_{2} \mathbf{0}$} \\
\cline { 2 - 4 } \cline { 7 - 8 } & $\mathbf{n}$ & Mean & \multicolumn{1}{c}{ SE } & & \multicolumn{1}{c}{$\mathbf{n}$} & Mean & \multicolumn{1}{c}{ SE } \\
\hline $2008-9$ & 1 & 645.9 & 46.2 & & 1 & $1,542.3$ & 74.8 \\
$2009-10$ & 12 & 729.5 & 118.7 & & 12 & 889.6 & 115.8 \\
$2010-11$ & 10 & 605.8 & 131.8 & & 10 & $13,01.0$ & 176.4 \\
\hline
\end{tabular}

the $2009-10$ nonbreeding season $(0.827 \pm 0.092)$ were similar. In contrast, the survival estimate for 20 individuals (15 male and 5 female) during the nonbreeding season of 2010-11 was markedly lower $(0.572 \pm 0.136)$ compared to previous years. The overall nonbreeding season survival estimate for lesser prairie-chickens on the study site was 0.721 (SE 0.0763). Based on posterior model probabilities, 46 percent of the model weight was supported by overall survival, whereas season (year) and gender were supported by 37 percent and 17 percent of the weights, respectively (table 5); however, all models were plausible based on delta AIC less than or equal to 2 . We documented 13 mortalities during the 3 nonbreeding seasons; we attributed 10 to avian predation, 2 to mammalian predation, and were unable to determine cause of mortality in 1 case.

\section{Discussion}

Information-based management is pivotal for monitoring and conserving imperiled species. The ability to assess and estimate home range, movements, habitat use, and survival is important not only for understanding the basic ecology of a species but also for aiding wildlife managers in making informed decisions (Heisey and Fuller 1985; Pollock and others, 1989; Murray, 2006). The observed home-range estimates for adult male and adult female lesser prairiechickens in our study were not dissimilar to those reported elsewhere. It is difficult, however, to directly compare our results to many other studies conducted on lesser prairiechickens. Most other studies provided results by using other methodology (for example, minimum convex polygon home range estimator), by sampling during different seasonal time periods, or by attempting to split the nonbreeding seasons into autumn (September 1-November 30) and winter (December 1-February 28). Although splitting home-range size into two distinct seasons may provide managers with additional information, our data did not support this action for three reasons. First, other studies were able to report information on juveniles. Juvenile home ranges are highly influenced by dispersal movements observed in the brood break up period (October through early January) (Taylor and Guthery, 1980b; Pitman and others, 2006a). Our sample of juveniles captured in the late summer and the fall were too small to analyze fall and winter movements. Second, when comparing movements within home ranges, other than one individual female that dispersed $14 \mathrm{~km}$ in 1 week in January, there were no atypical movements detected. Third, of the 23 lesser prairie-chickens in our study for which we estimated home ranges, the minimum number of locations used had to be liberalized for five individuals because of sample size restrictions. Splitting the available data into two distinct seasons would have weakened the home-range estimates.

Movements to seek sources of food, cover, or water may increase home-range sizes. Additionally, lesser 
Table 4. Nonbreeding-season habitat use relative to availability of lesser prairie-chickens (Tympanuchus pallidicinctus) in the Southern High Plains of Texas from September 1 through February 28 for 2008-9, 2009-10, and 2010-11.

[The data are based on 95\% Baileys confidence intervals comparing habitat types at telemetry relocation points to available habitat types within lesser prairiechicken home ranges]

\begin{tabular}{lrccl}
\hline $\begin{array}{c}\text { Habitat } \\
\text { type }\end{array}$ & Lower & Upper & $\begin{array}{c}\text { Mean proportion } \\
\text { availability }\end{array}$ & \multicolumn{1}{c}{$\begin{array}{c}\text { Use vs. } \\
\text { available }^{\mathbf{b}}\end{array}$} \\
\hline GRDS & 54.175 & 61.055 & 38.640 & More \\
MESA & .042 & 2.130 & 1.478 & No difference \\
REAG & .081 & 4.437 & 4.008 & No difference \\
SHRDB & .003 & 1.703 & 2.164 & Less \\
SHIDG & 17.884 & 28.734 & 23.973 & No difference \\
SHRDG & .399 & 3.773 & 8.970 & Less \\
SHIN & 5.515 & 12.863 & 11.59 & No difference \\
\hline
\end{tabular}

${ }^{a}$ Habitat types as classified in table 1. Three habitat categories (AGRI, CRPG, and GRDM) were removed from analysis because of failure to appear in any home ranges.

'If mean proportion availability falls below or above the lower and upper limits of the $95 \%$ confidence interval (CI), the habitat type is used more or less than available. If the mean proportion availability falls within the calculated CI, it is determined to have no difference.

prairie-chickens are also known to form large flocks over the winter months; Taylor and Guthery (1980b) found flocks with up to 100 lesser prairie-chickens feeding in a grain field. Davis and others (unpub. data, 2008) also suggested that lesser prairie-chickens originally may have benefited from small amounts of conversion of native grassland to cropland. We found no evidence of movements to agricultural fields as previously reported in the literature (Jones, 1964; Crawford and Bolen, 1976; Taylor and Guthery 1980b), nor did we observe any flock with 10 or more individuals at any point of the nonbreeding period outside of fall lekking males. The observed groups, both through radio-collared individuals and a separate camera study, were of both single sex and both sex groups. With approximately 97 percent of suitable habitat for lesser prairie-chickens now gone (Davis and others, unpub. data, 2008), habitat isolation (Mader, 1984) or the island effect (MacArthur and Wilson, 1967) may be yielding smaller home ranges and movements.

Previous research has shown nonbreeding lesser prairiechickens typically remain within $4.8 \mathrm{~km}$ of the lek of capture (Taylor and Guthery, 1980b; Kukal, 2010). Donaldson (1969) found lesser prairie-chickens used the sand shinnery oak habitat during the fall and winter months; however, Taylor and Guthery (1980b) speculated that lesser prairie-chickens will seek sources of greater cover during the fall months when sand shinnery oak drops its leaves. Similarly, Jones (1964) found that sand sagebrush was preferred after the loss of cover in the sand shinnery oak dominated areas. We found that the one cover type used greater than available by prairie-chickens in our study area contained sand shinnery oak that also had a grass component. We found that lesser prairie-chickens used only sand sagebrush dominated areas proportionally or less than was available. Areas that lacked or had low percentages of grassland cover were used either proportional to or less than available in our area. Additionally, a larger proportion of nonnative weeping lovegrass (Conservation Reserve Program grasslands) was avoided.

Our results indicate that a mixture of sand shinnery oak and grassland are a preferred cover type for lesser prairiechickens during the nonbreeding season; this conclusion is also consistent with results from elsewhere (Taylor and Guthery, 1980b; Olawsky and Smith, 1991). Approximately 70 percent of our study site contained at least some portions of sand shinnery oak; however, approximately 37.5 percent of the entire study site fell into the grassland dominated with sand shinnery oak habitat type. With roughly 40 percent of the study site falling into other sand shinnery oak categories (sand shinnery oak, sand shinnery oak dominated with bareground), increasing the grassland component through tebuthiuron treatment and/or grazing management may enhance wintering prairie-chicken habitat.

Our results suggest that lesser prairie-chickens typically remain within $3.2 \mathrm{~km}$ of the lek of capture in our study area, a range that is within what is reported in the literature (Taylor and Guthery, 1980b; Kukal, 2010). Our results also show that lesser prairie-chickens remain within $3.2 \mathrm{~km}$ of nearest known lek and the nearest available water. If large-scale management efforts are attainable, habitat management and conservation efforts would likely be most beneficial within $4.8 \mathrm{~km}$ of known leks, with areas consisting of sand shinnery oak or grassland dominated areas with sand shinnery oak likely holding the best potential for conservation efforts. If scope of management is restricted, however, our results suggest a focus on areas within $3.2 \mathrm{~km}$ of a water source may have the greatest benefit.

Understanding mortality and survival is an important component when monitoring and managing populations of imperiled species, such as the lesser prairie-chicken. We 
Table 5. Ranking of a priori candidate models predicting survival for lesser-prairie chickens (Tympanuchus pallidicinctus) in the Southern High Plains of Texas from September 1 through February 28 for 2008-9, 2009-10, and 2010-11.

[For each model, we display the second order Akaike Information Criterion (AICc) value, the $\triangle \mathrm{AIC}$ value representing the difference between the models AICc value and the lowest value ofAICc, $-2 \log$ likelihood, and model probability $\left.\left(\omega_{\mathrm{i}}\right)\right]$

\begin{tabular}{lccccc}
\hline Model & k & AICc & $\Delta$ AIC & $\begin{array}{c}- \text { 2log } \\
\text { likelihood }\end{array}$ & $\omega_{\mathbf{i}}$ \\
\hline S. & 1 & 70.92 & 0.00 & 68.84 & 0.46 \\
Year & 2 & 71.35 & .42 & 68.67 & .37 \\
Gender & 2 & 72.93 & 2.00 & 67.09 & .17 \\
\hline
\end{tabular}

found nonbreeding season survival rates that are among the highest reported for the species. Previously reported survival estimates range from 44 percent to 64 percent for males (Pitman and others, 2006b) and 43 percent to 70 percent for females (Hagen and others, 2007). In comparison, we found an overall nonbreeding season survival estimate of 72.1 percent, but even higher rates of 83.3 percent survival in 2008-9 and 82.2 percent in 2009-10. This finding indicates that nonbreeding season survival may not be a high priority issue as a limiting factor in our study area; however, our sample size, especially for females, was low. Future research towards fine scale habitat preference and survival of female and juvenile lesser prairie-chickens during the nonbreeding season may provide improved understanding for development of sound conservation strategies.

Knowledge of cause-specific mortality is essential for understanding facets of the ecology of lesser prairie-chickens. Over three nonbreeding seasons, we were able to assess cause specific mortality for 13 lesser prairie-chickens. We identified avian predation of 10 individuals, mammalian predation of 2 individuals, and 1 individual for which cause of death could not be identified. Although Wolfe and others (2007) classified fence collisions as a substantive cause of mortality among lesser prairie-chickens; during the three nonbreeding seasons of our study, we found no evidence of lesser prairie-chicken mortality that was due to fence collisions.

\section{References Cited}

Bailey, B.J.R., 1980, Large sample simultaneous confidence intervals for the multinomial probabilities based on transformations of the cell frequencies: Technometrics, v. 22 , p. $583-589$.

Calenge, Clément, 2006, The package 'adehabitat' for the $\mathrm{R}$ software-A tool for the analysis of space and habitat use by animals: Ecological Modelling, v. 197, p. 516-519.
Cherry, Steve, 1996, A comparison of confidence interval methods for habitat use-availability studies: Journal of Wildlife Management, v. 60, p. 653-658.

Cochran, W.W., and Lord, R.D., 1963, A radio-tracking system for wild animals: Journal of Wildlife Management, v. 27, p. 9-24.

Copelin, F.F., 1963, The lesser prairie-chicken in Oklahoma: Oklahoma City, Okla., Oklahoma Department of Wildlife Technical Bulletin 6 .

Crawford, J.A., and Bolen, E.G., 1976, Effects of land use on lesser prairie chickens in Texas: Journal of Wildlife Management, v. 40, p. 96-104.

Donaldson, D.D., 1969, Effect on lesser prairie chickens of brush control in western Oklahoma: Stillwater, Okla., Oklahoma State University, Ph.D. dissertation.

Fuhlendorf, S.D., Woodward, A.J.W., Leslie, D.M., Jr., and Shackford, J.S., 2002, Multi-scale effects of habitat loss and fragmentation on lesser prairie-chicken populations of the U.S. Southern Great Plains: Landscape Ecology, v. 17, p. 617-628.

Hagen, C.A., Jamison, B.E., Giesen, K.M., and Riley, T.Z., 2004, Guidelines for managing lesser prairie-chicken populations and their habitats: Wildlife Society Bulletin 32, p. 69-82.

Hagen, C.A., Pitman, J.C., Sandercock, B.K., Robel, R.J., and Applegate, R.D., 2005, Age-specific variation in apparent survival rates of male lesser prairie chickens: The Condor, v. 107 , p. $78-86$.

Hagen, C.A., Pitman, J.C., Sandercock, B.K., Robel, R.J., and Applegate, R.D., 2007, Age-specific survival and probable cause of mortality in female lesser prairie chickens: Journal of Wildlife Management, v. 71, p. 518-525.

Haukos, D.A., Smith, L.M., and Broda, G.S., 1989, Spring trapping of lesser prairie chickens: Journal of Field Ornithology, v. 61, p. 20-25.

Heisey, D.M., and Fuller, T.K., 1985, Evaluation of survival and cause-specific mortality rates using telemetry data: Journal of Wildlife Management, v. 49, p. 668-674.

Jamison, B.E., 2000, Lesser prairie-chicken chick survival, adult survival, and habitat selection and movements of males in fragmented rangelands in southwestern Kansas: Manhattan, Kans., Kansas State University, M.S. thesis.

Jones, R.E., 1964, The specific distinctness of the greater and lesser prairie chickens: The Auk, v. 81, p. 65-73.

Kukal, C.A., 2010, The over-winter ecology of lesser prairie chickens (Tympanuchus pallidicinctus) in the northeast Texas panhandle: Lubbock, Tex., Texas Tech University, M.S. thesis. 
MacArthur, R.H., and Wilson, E.O., 1967, The theory of island biogeography: Princeton, N.J., Princeton University.

Mader, H.J., 1984, Animal habitat isolation by roads and agricultural fields: Biological Conservation, v. 29, p. 81-96.

Mech, L.D., 1983, Handbook of animal radio-tracking: Minneapolis, Minn., University of Minnesota Press.

Murray, D.L., 2006, On improving telemetry based survival estimation: Journal of Wildlife Management, v. 70, p. $1530-1543$.

Neu, C.W., Byers, C.R., and Peek, J.M., 1974, A technique for analysis of utilization-availability data: Journal of Wildlife Management, v. 38, p. 541-545.

Olawsky, C.D., and Smith, L.M., 1991, Lesser prairiechicken densities on tebuthiuron-treated and untreated sand shinnery oak rangelands: Journal of Range Management, v. 44, p. $364-368$.

Pettit, R.D., 1979, Effects of picloram and tebuthiuron pellets on sand shinnery oak communities: Journal of Range Management, v. 32, p. 196-200.

Pitman, J.C., Jamison, B.E., Hagen, C.A., Robel, R.J., and Appelgate, R.D., 2006a, Brood break-up and juvenile dispersal of lesser prairie chickens in Kansas: Prairie Naturalist, v. 38, p. 85-99.

Pitman, J.C., Hagen, C.A., Jamison, B.E., Robel, R.J., Loughlin, T.M., and Appelgate, R.D., 2006b, Survival of juvenile lesser prairie chickens in Kansas: Wildlife Society Bulletin 34, p. 675-681.

Pollock, K.H., Winterstein, S.R., Bunck, C.M., and Curtis, P.D., 1989, Survival analysis in telemetry studies-The staggered entry design: Journal of Wildlife Management, v. 53, p. $7-15$.

Railroad Commission of Texas, 2006, Oil well counts by county as of September 2006: accessed March 14, 2012, at http://www.rrc.state.tx.us/data/wells/wellcount/ oilwlct0906.pdf.
Taylor, M.A., and Guthery, F.S., 1980a, Status, ecology, and management of the lesser prairie chicken: Fort Collins, Colo., Rocky Mountain Forest and Range Experiment Station, USDA Forest Service General Technical Report RM-77, $15 \mathrm{p}$.

Taylor, M.A., and Guthery, F.S., 1980b, Fall-winter movements, ranges, and habitat use of lesser prairie chickens: Journal of Wildlife Management, v. 44, p. 521-524.

Texas Tech University, 2011, West Texas Mesonet: accessed March 14, 2012, at http://www.mesonet.ttu.edu/.

Toole, B.E., 2005, Survival, seasonal movements, and cover use by lesser prairie chickens in the Texas panhandle: College Station, Tex., Texas A\&M University, M.S. thesis.

U.S. Fish and Wildlife Service, 2008, Endangered and threatened wildlife and plants; review of native species that are candidates for listing as endangered or threatened. Federal Register 73:75176-75244.

Vermeire, L.T., and Wester, D.B., 2001, Shinnery oak poisoning of rangeland cattle-Causes, effects and solutions: Rangelands, v. 23, p. 19-21.

Warner, R.E., and Etter, S.L., 1983, Reproduction and survival of radio marked hen ring-necked pheasants in Illinois: Journal of Wildlife Management, v. 47, p. 369-375.

Worton, B.J., 1989, Kernel methods for estimating the utilization distribution in home-range studies: Ecology, v. 70 , p. $164-168$.

Wolfe, D.H., Patten, M.A., Shochat, Eyal, Pruett, C.L., and Sherrod, S.K., 2007, Causes and patterns of mortality in lesser prairie chickens Tympanuchus pallidicinctus and implications for management: Wildlife Biology, v. 13, p. $95-104$. 


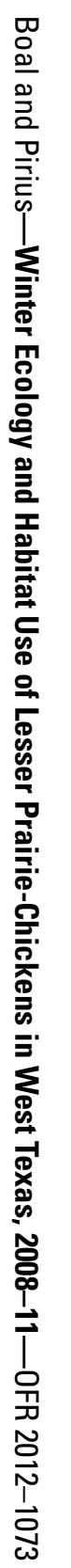

